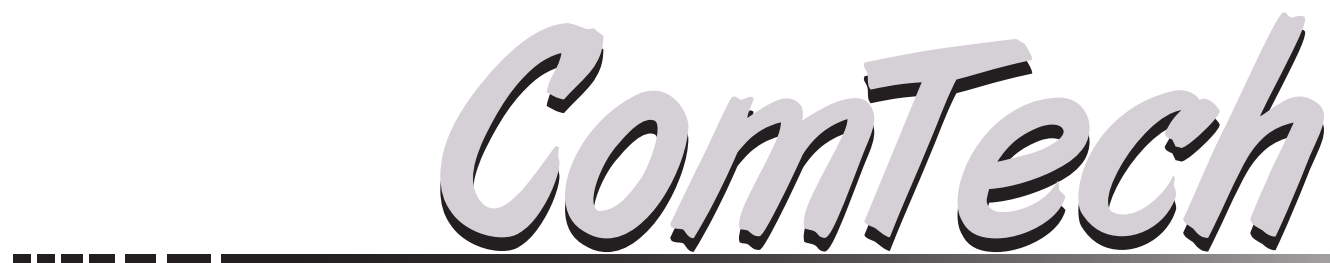

\title{
Computer, Mathematics and Engineering Applications
}

\section{Editor in Chief}

Ngarap Imanuel Manik

\section{Managing Editors}

Arta Moro Sundjaja

Noerlina

\section{International Editor Board}

Agustinus Oey

Dase Hunaefi

Kiyota Hashimoto

Daniel M. Wonohadidjojo

Eddy Wiyanto

Gisela Nina Sevani

Humiras Hardi Purba

Leon Andretti Abdillah

Rino Nugroho

Tati Nurhayati

Zulkardi

Fergyanto E. Gunawan

Firza Utama

Ingrid Suryanti Surono

Irpan Hidayat

Lukas Siswanto Tanutama

Rinda Hedwig

Tota Pirdo Kasih

Tri Pudjadi

Wikaria Gazali
Mathematics and Statistics Department, Bina Nusantara University, Indonesia

Information System Department, Bina Nusantara University, Indonesia Information System Department, Bina Nusantara University, Indonesia

\section{Language and Layout Editor}

Eka Yanti Pangputri

Dina Nurfitria

Atmawati

Holil

\section{Secretariat}

Haryo Sutanto

\author{
Korea Advanced Institute of Science and Technology (KAIST), Republic of Korea \\ Free University of Bozen-Bolzano, Italy \\ PSU Phuket, Thailand \\ Ciputra University, Indonesia \\ Krida Wacana Christian University, Indonesia \\ Krida Wacana Christian University, Indonesia \\ Mercu Buana University, Indonesia \\ Bina Darma University, Indonesia \\ Sebelas Maret University, Indonesia \\ Bogor Agricultural Institute, Indonesia \\ Sriwijaya University, Indonesia \\ Bina Nusantara University, Indonesia \\ Bina Nusantara University, Indonesia \\ Bina Nusantara University, Indonesia \\ Bina Nusantara University, Indonesia \\ Bina Nusantara University, Indonesia \\ Bina Nusantara University, Indonesia \\ Bina Nusantara University, Indonesia \\ Bina Nusantara University, Indonesia \\ Bina Nusantara University, Indonesia
}

Bina Nusantara University, Indonesia Bina Nusantara University, Indonesia Bina Nusantara University, Indonesia Bina Nusantara University, Indonesia

Bina Nusantara University, Indonesia

\section{Description}

COMTECH is a semiannual journal, published in June and December. COMTECH is a forum for lecturers, academics, researchers, practitioners, and students to convey and share knowledge in the form of empirical and theoretical research articles, case studies, and review of the literature. Editors invite professional education, research, entrepreneurs and students to participate in spreading the development of science in the fields of Information Systems, Architecture, Civil Engineering, Computer Engineering, Industrial Engineering, Food Technology, Computer Science, Mathematics, and Statistics through this scientific journal. Currently, ComTech has been indexed by CrossRef, ASEAN Citation Index, Directory of Open Access Journals (DOAJ), Science and Technology Index (SINTA), Microsoft Academic Search, Google Scholar, Academic Resource Index (ResearchBib) and Indonesian Research Repository (Neliti). The journal can be accessed online on http://journal.binus.ac.id/index.php/comtech. Authors should refer to the guidelines when preparing their articles.

Research and Technology Transfer Office, Bina Nusantara University, Anggrek Campus, Jl.Kebon Jeruk Raya 27, Kebon Jeruk, Jakarta Barat 11530, Tel. +621-5350660 ext. 1705/1708, Fax.+621-5300244, E-mail: asundjaja@binus.edu, hsutanto@binus.edu, comtech@binus.edu, Url: http://journal.binus. ac.id/index.php/comtech, FB: https://www.facebook.com/ComTechBinus 


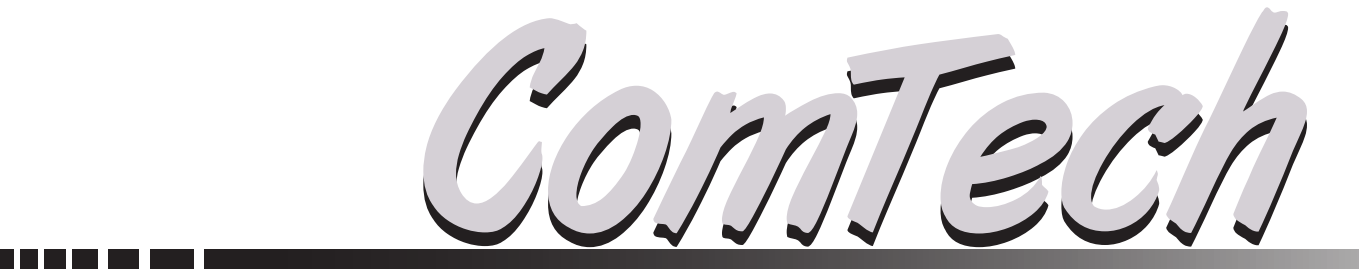

Computer, Mathematics and Engineering Applications

\section{TABLE OF CONTENTS}

Shelvy Kurniawan and Steven Sanjaya Raphaeli

Optimizing Production Process through Production Planning and Inventory Management in Motorcycle

Chains Manufacturer

Ong Alexander Ang and Arta Moro Sundjaja

The Development of E-Procurement System for an IT Consultant Company

Veronica

E-Commerce Feasibility Analysis and Strategic Planning to Develop a Small-Medium Enterprise Project

in Banking Company

Ikwuoche John David, Osebekwin Ebenezer Asiribo,

and Hussaini Garba Dikko

Nonlinear Split-Plot Design Model in Parameters Estimation using Estimated Generalized

Least Square -Maximum Likelihood Estimation.

Mychael Maoeretz Engel

Android Based Thesis Mentoring System Using Google Firebase ....

Index 